\title{
NAVEGAR \\ ENTRE SILÊNCIOS
}

Do!

dx.doi.org/10.11606/issn.2525-

3123.gis.2020.171002

ORCID

orcid.org/0000-0002-4055-9533
Cánepa Koch, Gisela e Ingrid Kummels, orgs. 2018. Fotografía en América Latina: imágenes e identidades a través del tiempo y el espacio. Lima: Instituto de Estudios Peruanos.

\section{LUÍSA VALENTINI}

Universidade de São Paulo, São Paulo, SP, Brasil, 05508-010 fla@usp.br

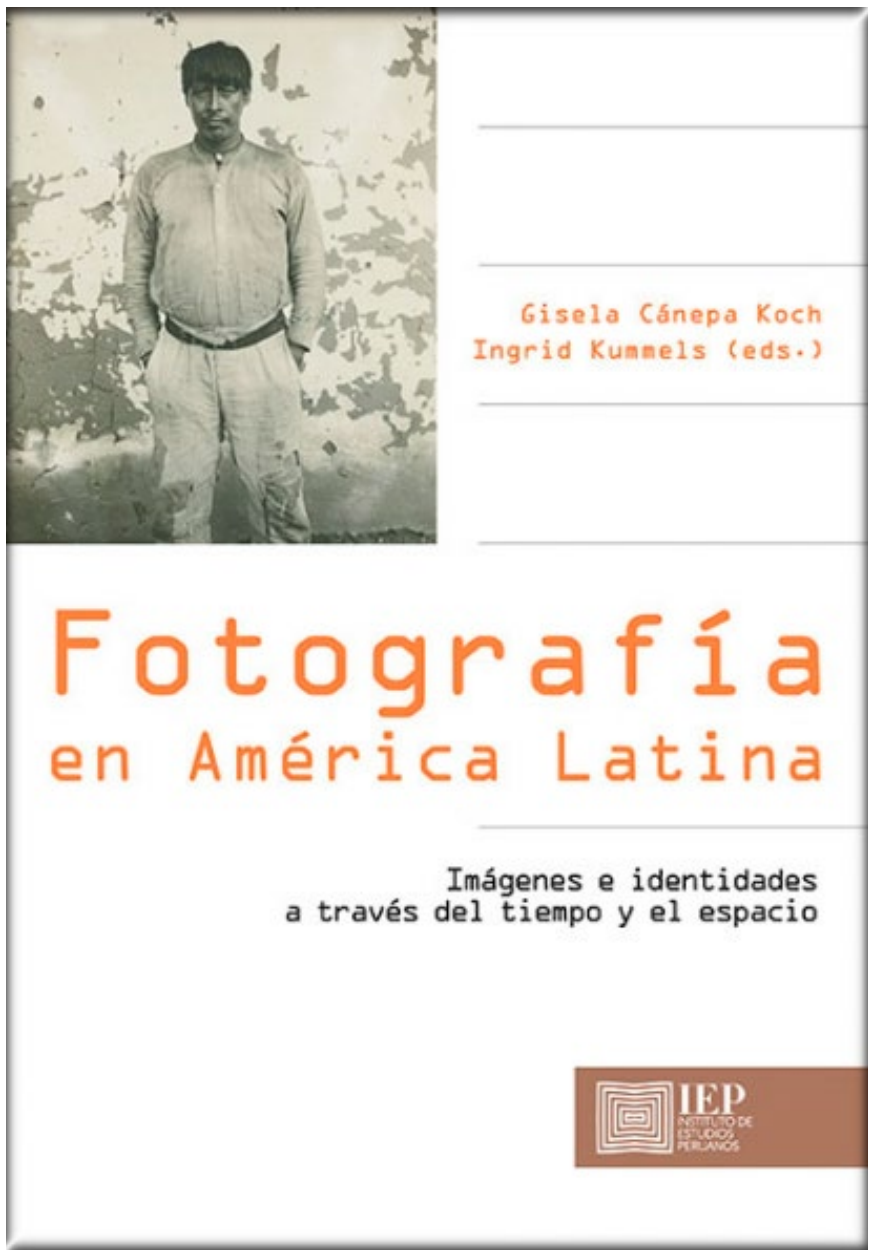


Os antropólogos que frequentamos conjuntos documentais formados por outros antropólogos encontramos com frequência, entre os diversos artefatos mediadores do conhecimento na disciplina, um certo acúmulo de registros fotográficos. Estes podem ter sido feitos pelos próprios pesquisadores ou chegado às suas mãos, vindos de outros fotógrafos; podem ter sido realizados para efeito de prova científica, de registro destinado a posterior exame, de sistematização de paisagens e contextos, e para identificação de interlocutores; ou, ainda, sem se dirigir necessária e diretamente a essas acepções, como recortes de um processo de conhecimento travado na imersão e na convivência, constituindo diferentes linguagens conforme eles compõem conjuntos. E não é novidade que o grande volume de coleções fotográficas produzido em meio à antropologia nos séculos XIX e XX exige não apenas um tratamento técnico adequado, mas uma reflexão metodológica cuidadosa, que se fundamente de modo não presentista e seja alimentada pelo acúmulo crítico da antropologia nos dias de hoje, possibilitando sua adequada caracterização, seja para efeito de guarda, seja para sua circulação e extroversão.

o livro Fotografía en América Latina: imágenes e identidades a través del tiempo y el espacio, editado em língua espanhola pelo Instituto de Estudios Peruanos, oferece uma ocasião rica para fruir do efeito caleidoscópico propiciado por trabalhos que lidam com diferentes acervos fotográficos na singularidade dos campos de relações em que cada um deles se constrói. O livro foi organizado pelas professoras Gisela Cánepa Koch, da Pontifícia Universidade Católica do Peru, em Lima, e Ingrid Kummels, do Instituto de Estudos Latino-Americanos da Universidade Livre de Berlim, reunindo trabalhos delas próprias e de mais cinco pesquisadores engajados nos trânsitos de acervos fotográficos em diferentes percursos realizados a partir de seus acúmulos de origem - na sua maioria em reservas técnicas, à espera de exposições - e para o que se espera (embora nem sempre aconteça) serem reencontros com os lugares e pessoas em meio aos quais se fotografou. Num processo bastante característico do nosso momento histórico, os projetos de digitalização são uma condição central à concepção desse tipo de projeto.

Resumir as potencialidades dos sete estudos reunidos no livro é uma tarefa ingrata e, ironicamente, própria da nossa época, em que ao mesmo tempo proliferam as tensões críticas sob as quais os antropólogos trabalham, e em que a coletânea se constitui como o gênero editorial que melhor modela os encontros e trocas estabelecidos numa comunidade científica numerosa, diversa e internacionalizada. Os estudos parecem ter em comum a operação de uma tríade de perspectivas, sendo a visada de cada pesquisador constelada com aquelas construídas nos acervos fotográficos tratados, mormente produzidos por etnógrafos entre povos indígenas que habitam a América hispânica (com a exceção de dois artigos 
que não tematizam centralmente a dimensão étnica, ambos tratando de acervos fotográficos familiares), e com aquelas oriundas de diferentes situações em que se busca elicitar discursos locais a respeito dos materiais. Os conjuntos fotográficos parecem, assim, cumprir o papel de refratores temporais de discursos locais a respeito da cultura, da identidade e dos discursos científicos que as constroem enquanto problemas.

No primeiro artigo, Michael Kraus tematiza um projeto de digitalização e exposição de fotografias feitas entre povos indígenas, no Museu Etnológico de Berlim, por nomes heroicos da primeira etnografia americanista de inclinação culturalista, como Karl von den Steinen (18551929), Max Schmidt (1874-1950), Theodor Koch-Grünberg (1872-1924) e Erland Nordenskiöld (1877-1932), oferecendo uma perspectiva interessante para a exposição de retratos e as possibilidades e limites colocados pela tipologização e despersonalização produzida pelos gêneros visuais da passagem do XIX para o XX. Já no segundo, Gisela Cánepa Koch recupera a coleção de Heinrich Brüning, distribuída entre o Museum für Völkerkunde de Hamburgo e o Museu Etnológico de Berlim, como ocasião para descrever seu papel na caracterização de uma identidade cultural muchik no Peru, processo que por sua vez se apresenta como contexto determinante para projetos de digitalização e circulação de materiais num ambiente renovado pelo agenciamento do trabalho de Brüning pelo próprio grupo Muchik, no presente.

No terceiro artigo, Aura Lisette Reyes recupera o discurso visual de Konrad Theodor Preuss e encontra nele a oportunidade de falar de uma série de desconfortos com relação à produção do registro visual etnográfico, seja nos esforços e constrangimentos atravessados pelo pesquisador que procurara fazer registros científicos e fidedignos de uma paisagem cultural arqueológica e etnográfica, seja nos silêncios e embaraços constatados na escuta de leituras das imagens feitas por interlocutores do grupo Kogui, em trabalho de campo na Colômbia. Na quarta discussão, Mariana da Costa Petroni recupera os acervos visuais produzidos no contexto de uma etnografia culturalista, de inclinação integracionista, realizada pelo mexicano Julio de la Fuente entre os Zapotecas mexicanos. Em seu trabalho, a dimensão integradora da perspectiva culturalista histórica articulada em torno da noção de aculturação se desdobra, em reencontros com leitores de imagens zapotecas, em discursos também pensando a mudança cultural na dimensão diacrônica, mas agora na linguagem da identidade cultural articulada desde diferentes pontos de vista zapotecas.

o quinto trabalho é de Ingrid Kummels, que apresenta a circulação de um acervo histórica e pessoalmente mais aproximado de sua própria trajetória, as fotografias do antropólogo - e seu esposo - Manfred Schäfer registrando as lutas dos Ashaninka e Nomatsiguenga da Amazônia peruana. 
Os registros, realizados a partir dos anos 1970, já numa perspectiva de action anthropology, foram mobilizados em diferentes situações de militância indigenista e ambientalista. No retorno de Ingrid Kummels com as imagens alguns anos após o falecimento de Schäfer, estas são reativadas não apenas para o engajamento político, mas para um reconhecimento quase lúdico de seus interlocutores, que se direciona a eles mesmos e a seus conhecidos (e, portanto, não simplesmente como portadores de culturas ou identidades étnicas) nas fotografias. A procura por familiares e conhecidos, aliás, aparece de modo interessantemente recorrente nos textos, embora me pareça insuficientemente explorada como uma questão mais geral e informativa: afinal, o que dura (ou deve durar) são culturas ou são as pessoas e as redes, mormente familiares, que elas tecem?

A questão da presença por meio da fotografia reaparece no artigo de Mercedes Figueroa, que trata de fotos de família de estudantes universitários desaparecidos e assassinados pelo terrorismo de Estado no Peru dos anos 1990. Aqui parece se inverter o gesto de buscar a si próprio em álbuns alheios, constando os álbuns familiares como lugares residuais da presença de pessoas perdidas e como substrato para a resistência em meio à potencial desmobilização gerada pelo sentimento de luto. 0 engajamento da pesquisadora com a transformação de fotos familiares em imagens públicas, em meio a situações de severo luto familiar, oferece ao conjunto da coletânea uma ocasião para a declinação mais contundente do tema da pessoa e de sua duração. Ainda tratando mais diretamente da visibilização de traumas de conflitos políticos em contexto não necessariamente indígena, María Eugenia Ulfe e Ximena Málaga Sabogal acompanham a formação de conjuntos fotográficos e o agenciamento público de fotografias no contexto da Comissão da Verdade e da Reconciliação na província de Huancasancos, gravemente afetada pela violência e o autoritarismo entre os anos 1980 e 2000. Aqui, a potência elicitatória de memórias a partir da montagem de uma exposição fotográfica parece adquirir tensão máxima, não simplesmente pela proximidade histórica dos eventos rememorados, mas também pelos efeitos contrastivos e comparativos necessariamente suscitados por qualquer montagem: o que fica dentro e o que fica fora de uma seleção?

Desses diferentes modos, a discussão entabulada no livro tem um de seus disparadores na potência da leitura fotográfica. A sua vantagem comparativa para a comunicação em torno de temas históricos, em contraste com as diferentes mediações necessárias ao trabalho em torno de materiais textuais, situa a fotografia, nestes como em tantos outros trabalhos, como um poderoso meio propiciador de colaboração em pesquisa. E este caminho é interessante não simplesmente por suas conotações de dádiva, devolução e reencontro, mas também pelos silêncios, ruídos e assimetrias que cercam cada um dos circuitos de imagens, 
paisagens, visadas e falas aqui mapeados, colocando de algum modo os pesquisadores assim implicados em uma situação de risco compartilhado com seus interlocutores, risco que nem sempre é bem reconhecido quando se trata do trabalho dito "de arquivo".

E se nisso não há muito de novidade - como tampouco há na proliferação de encontros, narrativas e trocas em que se discute a antropologia enquanto prática feita de deslocamentos e tensões -, é difícil para uma estudiosa do próprio meio antropológico no Brasil evitar, na leitura do livro, certa melancolia em reconhecer uma série de pontos cegos dos nossos próprios territórios de familiaridade etnográfica. Antes de mais nada, trata-se da produção de pesquisadores oriundos de países hispano-americanos e da Alemanha - com a importante exceção de Petroni, brasileira -, com os quais, apesar de haver esforços de intercâmbio, a área dedicada às sociedades ameríndias troca ainda significativamente menos que com colegas anglófonos e francófonos. É irônico, para não dizer um tanto vergonhoso, que possamos acessar a produção de pesquisadores falantes nativos do alemão exatamente por uma publicação feita em espanhol num país vizinho, cuja produção entre nós circula pouquíssimo. Soma-se a isso, de uma perspectiva histórica sobre a disciplina, nossa consideração ainda vaga, algo míope (ou, em vocabulário mais afeito aos povos indígenas, esquecida), no que diz respeito aos estudos etnográficos produzidos em língua alemã desde o século XIX - miopia que se deve a processos históricos de desaquecimento de relações, traduções e leituras, de mudanças de vocabulário e processos de trabalho. E isso tudo se dá apesar da importância dessa produção nos inícios do chamado "americanismo tropical" e da sua presença, se não numerosa, marcante no Brasil, em particular na presença local das figuras de Curt Nimuendajú e de Herbert Baldus.

Essa reação de melancolia tem certamente algo de exagero, porque já se tornam mais numerosos, no Brasil, os estudos sobre estas e outras figuras do americanismo germanófono, fomentados por décadas de trabalho de pesquisa, tanto em direção das histórias e historicidades dos povos indígenas sul-americanos, quanto da história da própria antropologia. Sob investigação mais atenta, esse sentimento pode ganhar outro rendimento, propriamente teórico e metodológico, para pensar o painel de estudos aí apresentado. A melancolia nos sugere que, nesta espécie de multidão acadêmica que hoje habitamos, e na proliferação de informações em meio à qual trabalhamos, o trabalho antropológico possível seja mesmo o de um tipo de erudição de narrativas fragmentárias cuja dispersão em escalas e territórios variáveis não possa receber um ponto de parada. A variedade de territórios, reações e articulações colocada à questão da circulação das fotografias no livro organizado por Cánepa e Kummels constitui, assim, uma boa oportunidade de perambulação por 
territórios e de descoberta de vizinhanças e estranhezas insuspeitas. o formato "coletânea" gera, nesse contato preliminar com uma outra comunidade de estudo, uma espécie de insatisfação na medida em que os detalhes oferecidos por cada artigo não parecem ser bastantes, na extensão a que estão limitados, para saciar a curiosidade do leitor estrangeiro. Tal insatisfação é certamente benfazeja porquanto nos mobiliza a buscar novas referências e possíveis interlocuções, ao mesmo tempo que ilumina nossas lacunas de repertório.

Há ainda, no entanto, outro tipo de lacuna e melancolia que cerca a leitura do livro e que diz respeito ao encontro com os vocabulários de trabalho usados nas tertúlias estrangeiras. Pergunto-me se a sensação de insuficiência que pode e deve nos mobilizar a uma maior troca não diz respeito, não simplesmente à extensão dos trabalhos e ao desencontro de territórios das nossas frequentações, mas também às possibilidades colocadas pela noção de identidade cultural para falar de encontros prenhes de ruídos, dúvidas e desconfianças, cujas alegrias parecem dizer mais respeito a ver a si próprio como pessoa e menos como cultura. Retorna aqui, desse modo, um problema hoje tão inquietante quanto sempre, em particular para antropólogos: até que ponto a caracterização da diferença nos termos da cultura e a conexão de pessoas, famílias e territórios no vocabulário culturalista é de fato capaz de se contrapor às diversas modalidades de violência que atravessam a história da colonização e da instauração das desigualdades na América do Sul? E em que medida ela é capaz de falar de motivações e afetos implicados no reencontro de coletividades com as imagens que se dizem ser suas?

O livro organizado por Cánepa e Kummels não fala simplesmente de fotografias e de etnografias, mas também de um contracampo de empreendimentos extrativistas, devastação florestal, imposição linguística e de hábitos, e de guerrilhas e desaparecimentos políticos. Ampliando desse modo a nossa perspectiva, o efeito de conexões entre pessoas e momentos no espaço e no tempo propiciado por coleções fotográficas pode - como parece ser uma ideia forte no livro - articular visibilidades e identidades culturais, conformando em casos concretos a já amplamente aceita, talvez até óbvia, ideia de dinamicidade das culturas. Desse ponto de vista, é possível que tais coleções ofereçam um espaço de reflexão e reação à dimensão avassaladora de uma historicidade que se apresenta como violência. Mas as autoras e autor parecem bastante conscientes de relações de poder, tensões, sofrimento e esquecimentos cujo sentido exato não é possível precisar - eles também têm sua persistência no tempo.

Talvez esses impasses estejam dados, e as coleções se conformem como uma espécie de herança irrecusável com a qual cada uma das partes implicadas nos encontros mediados por fotografias terá de lidar usando 
suas próprias ferramentas; e, talvez, entre essas heranças estejam as próprias noções de cultura e de identidade. Diante dos desencontros e silêncios entre essas diferentes comunidades que fazem e refazem trocas e contatos, aproximando-se, inquirindo-se, apresentando-se e estranhando-se mutuamente (mas não igualmente, e nem indiferentemente), as coleções fotográficas parecem aqui permitir, sobretudo, o começo de conversas. Nesse momento, o procedimento mais seguro se assemelha mais a uma navegação de cabotagem que à abordagem, colonização ou o preenchimento das lacunas e silêncios. Que estes problemas se apresentem de modo tão claro é um mérito do livro e da dedicação dos pesquisadores que nele compartilham seus caminhos. Talvez novas alianças possam se revelar nos mesmos contracampos, silêncios, vazios e obscuridades em que a inspiração humboldtiana para o mapeamento e o inventário das paisagens e culturas parecia proliferar descobertas, tipologias e ilustrações; e talvez possamos, desse modo, de fato demonstrar o devido respeito à densidade das florestas e montanhas aquém-Atlântico, e aos muitos Völker que as habitavam e habitam ainda.

LUÍSA VALENTINI é doutora em Antropologia Social pela Universidade de São Paulo (USP). Autora de Um laboratório de antropologia: o encontro entre Mário de Andrade, Dina Dreyfus e Claude Lévi-Strauss (Fapesp/Alameda, 2013). Dedica-se a questões concernentes à documentação relativa a populações tradicionais no Brasil, em particular a documentação oriunda de pesquisa. E-mail: luisa.valentini@gmail.com 